\title{
REVISITANDO A RELAÇÃO ENTRE ÉTICA E DIREITO NA METAFÍSICA DOS COSTUMES
}

Revisiting the relationship between Ethics and Law in the Metaphysics of Morals

\author{
Nilmar Pellizzaro *
}

Resumo: O presente estudo investiga a natureza da relação entre Ética e Direito na Metafísica dos Costumes. Para isso, parte de uma análise comparativa entre três interpretações (tese da independência, tese da dependência e tese da complementariedade) mostrando, a partir de uma investigação do texto de Kant, por que a tese da complementariedade é mais defensável. Além disso, corrobora com esta perspectiva outra tese por nós defendida acerca do problema da analiticidade no Direito, segundo a qual o Direito, ainda que analiticamente derivado da liberdade externa, deverá ser complementado por um princípio sintético (a vontade unida do povo) a fim de não ficar fora do sistema da Metafísica dos costumes. A conclusão a que chegaremos aponta que, apesar de algumas inconsistências por parte de Kant quando trata da natureza dos deveres éticos e jurídicos, Direito e Ética são assumidos por ele como dois ramos do sistema moral que se complementam e descrevem o domínio total da razão prática no contexto da ação humana, seja no âmbito interno da liberdade, seja no externo.

Palavras-chave: Kant, Ética, Direito, Deveres jurídicos, Deveres de virtude.

This study investigates the nature of the relationship between Ethics and Law in the Metaphysics of Morals. It is based on a comparative analysis between three interpretations (thesis of independence, thesis of dependency and thesis of complementarity) and, from Kant's text, argues that the thesis of complementarity is the most defensible one. Moreover, this perspective is supported by another

* Doutor em Filosofia pela Universidade Federal de Santa Catarina (UFSC). Artigo recebido em 12/03/2018 e aprovado para publicação em 11/02/2019. 
thesis regarding the issue of analyticity in Law. It states that, although the Law is analytically derived from external freedom, it should be complemented by a synthetic principle (the united will of the people) in order to remain within the system of the Metaphysics of Morals. We thus reach the conclusion that, despite his inconsistencies when dealing with the nature of ethical and legal duties, Kant understands Law and Ethics as two branches of the moral system that complement and describe the total mastery of practical reason in the context of human action, whether in the inner or outer sphere of freedom.

Key-words: Kant, Ethics, Law, Legal duties, Ethical duties.

\section{Introdução}

questão da relação entre Ética e Direito tem sido um tema muito
discutido entre os Kantianos e ainda hoje não é ponto pacífico,
especialmente pela forma paradoxal com que Kant a trata na $M e-$ tafísica dos Costumes ${ }^{1}$. Tendo isso em vista, o presente estudo parte de uma breve análise comparativa entre três importantes teses a respeito dessa relação e procura mostrar os equívocos de duas dessas leituras e que uma delas, apesar de sumariamente apresentada, é respaldada no texto da Metafísica dos Costumes. Resumidamente, a tese da dependência atribui uma dependência do Direito em relação à Ética devido à interpretação de que a normatividade dos deveres jurídicos seria proveniente do imperativo categórico, que é próprio da Ética; já a tese da independência procura mostrar que o imperativo da Ética não seria a fonte dos deveres jurídicos e que o Direito (pelo menos o estrito) se resumiria a uma autorização para coagir, não sendo ele, na sua essência, um sistema prescritivo; finalmente a tese da complementariedade (assim por nós denominada por falta de um termo mais apropriado) aponta que Ética e Direito seriam sistemas independentes, muito embora ambos sejam provenientes da razão prática, isto é, do sistema moral.

Num primeiro momento, analisaremos os argumentos de duas dessas teses (tese da dependência e tese da independência) evidenciando que ambas fazem uma leitura equivocada do pensamento de Kant e que por isso a tese da complementariedade parece traduzir melhor o núcleo do seu pensamento a esse respeito. Num segundo momento, e tomando como

\footnotetext{
${ }^{1}$ As obras de Kant serão citadas conforme a paginação da Akademie-Ausgabe:

Metafísica dos Costumes. 2ª . ed. Trad. José Lamego. Lisboa: Fundação Calouste Gulbenkian, 2011. (MS, AA 06).

Sobre a expressão corrente: isto pode ser correto na teoria, mas nada vale na prática. Trad. Artur Morão. In: A paz perpétua e outros opúsculos. Lisboa: Edições 70, 2008. (TP AA 08).
} 
background a tese da complementariedade, faremos uma incursão pelo texto da Metafísica dos Costumes procurando mostrar como esta tese encontra eco no texto e pode ser justificada, e que, apesar de alguns deslizes por parte de Kant (quando trata da divisão dos deveres éticos e jurídicos) que tornam o texto paradoxal, é possível perceber ali claramente esta relação de complementariedade entre Ética e Direito. Além disso, para uma melhor compreensão desta relação, teremos que esclarecer o problema da analiticidade no Direito (e esta é uma contribuição original deste trabalho), já que a tese da complementariedade só poderá ser sustentada se pudermos demonstrar que o Direito, ainda que analiticamente derivado da liberdade externa, deverá ser complementado por um princípio sintético (a vontade unida do povo) ${ }^{2}$ a fim de não ficar fora do sistema da Metafísica dos costumes, afinal, a Metafísica, para poder manter-se dentro do sistema crítico, precisa estar fundada em juízos sintéticos a priori. Chegaremos à conclusão de que Direito e Ética são dois ramos da Metafísica dos costumes, são dois subsistemas que se complementam e descrevem o domínio total da razão prática no contexto da ação humana, seja no âmbito interno da liberdade, seja no externo. E por isso o Direito não pode ser dissolvido ou estar submetido à Ética (como propõe a tese da dependência), ao mesmo tempo ele não pode ser visto como um sistema desconexo da normatividade prático-jurídica da razão (tese da independência).

\section{A tese da independência}

Como o próprio nome já indica, a tese da independência defende que o sistema do Direito possui uma independência em relação ao imperativo categórico da Ética. Willaschek, um dos defensores desta posição, argumenta que o Direito é regulado por uma legislação externa e por isso a coerção é sempre externa, de modo que, do ponto de vista de quem obedece à lei, o móbil para o seu cumprimento poderá ter uma origem patológica, já que não exige que o dever seja a causa impulsionadora da ação. Embora os deveres jurídicos possam ser cumpridos com virtude (Ética), tal exigência não poderia ser feita ao Direito, já que as leis jurídicas só exigem legalidade no seu cumprimento, isto é, uma conformação externa da ação com a lei (tese da externalidade). Por sua vez, a Ética é regulada por uma legislação interna, a qual exige que o cumprimento do dever seja motivado pela própria ideia do dever e isto por meio de uma exigência incondicional que nos faz o imperativo categórico.

\footnotetext{
${ }^{2}$ Conforme aponta Colomer, Kant utiliza várias expressões quando se refere à vontade unida, as quais devem ser consideradas intercambiáveis, tais como: vontade universal, vontade geral, vontade coletiva, vontade comum, vontade unificada. Cf. COLOMER MARTÍN-CALERO, José Luis. La teoria de la justicia de Immanuel Kant. Madrid: Centro de estudios constitucionales, 1995, p. 291.
} 
Segundo Willaschek, o caráter prescritivo de uma lei ética se dá sempre que há um conflito entre o que o imperativo afirma como objetivamente necessário e aquilo que é subjetivamente desejado, isto é, quando aquilo que o imperativo ordena realizar por dever está em dissonância com uma subjetividade patologicamente determinada por outros móbeis, o que deixa margem para o sujeito adequar sua disposição à lei ou não. Ora, na medida em que o imperativo categórico faz uma exigência de adesão incondicional à sua lei, e, portanto, que se cumpra o que a lei determina motivado pelo dever, as leis jurídicas não podem ser derivadas dele, pois estas são reguladas por uma legislação externa, abstraindo-se de qualquer motivação interna e por isso não podem ser vistas como um imperativo incondicional. Também não poderiam ser vinculadas a um imperativo hipotético, pois tomando como exemplo a fórmula geral que diz: "se queres evitar ser punido, deves fazer ' $\mathrm{x}$ '”, neste caso os destinatários da lei seriam somente aqueles que visam apenas evitar a punição e não todos os demais súditos que a cumpririam por outras razões. Disso o autor conclui que os deveres jurídicos não podem ser considerados como imperativos derivados da Ética e que, portanto, a tese da externalidade parece entrar em conflito e até excluir a tese da prescriptividade ${ }^{3}$. O autor ainda entende que as leis jurídicas podem ser consideradas normativas de um ponto de vista teórico, no sentido de que são regras contra-factuais, porém não podem ser prescritivas no sentido prático e exigir que seus destinatários ajam de acordo com elas. Em outros termos, além da coerção externa pelo Estado, não há nada que possa obrigar alguém a cumprir uma lei jurídica, e assim, a ideia de obrigação (interna) que é própria da Ética, não faria sentido no âmbito jurídico.

Com isso, a conclusão a que chega Willaschek é de que não haveria a ideia de obrigação ou mesmo de prescrição no Direito, mas apenas uma autorização para coagir de acordo com uma lei universal de liberdade. $\mathrm{O}$ Direito seria uma instância coercitiva daqueles arbítrios que interferem na liberdade dos demais e colocam-se em conflito com um uso universal da liberdade. Por isso, ao Direito não cabe tanto a tarefa de determinar o que se deve ou não fazer, mas muito mais impedir e limitar um uso nocivo da própria liberdade em relação aos demais. Segundo o autor, esta visão não prescritiva do Direito Kant a teria demonstrado por uma analogia com a terceira lei newtoniana do movimento dos corpos, segundo a qual, uma força que vise limitar um comportamento ilegal, deve ser proporcional à força que resiste a um uso universal da liberdade, nem maior, nem menor. Ou seja, a coerção deve ser proporcional ao obstáculo que se impõe a um uso correto da liberdade.

\footnotetext{
${ }^{3}$ Cf. WILLASCHEK, M. Which Imperatives for Right? On the non-prescriptive character of juridical laws in Kant's Metaphysics of Morals. In: TIMMONS, Mark (Ed). Kant's Metaphysics of Morals. Interpretative essays. Oxford: Oxford University Press, 2002, p. 67-75.
} 
Portanto, para Willaschek somente de uma perspectiva ética as leis jurídicas poderiam ser tomadas como prescritivas (como deveres éticos indiretos), porém da perspectiva do Direito estrito seriam apenas leis descritivas que permitiriam, em nome de um uso universal da liberdade, uma autorização para coagir ${ }^{4}$. Mesmo a Ética podendo assumir os deveres jurídicos indiretamente como seus, isso não faz com que o Direito esteja submetido a ela, afinal, as leis jurídicas são independentes do imperativo ético e o Direito pode ser compreendido, a partir da tese da externalidade, puramente como uma exigência necessária à convivência, a qual deverá ser regulada pelas leis da liberdade externa.

Um segundo autor que trabalha com a tese da independência é Allen Wood. Segundo ele, o princípio do Direito não é derivado do imperativo categórico, tratando-se antes de um postulado puramente explicativo do conceito de Direito, o qual pode ser identificado com o conceito de coação externa de acordo com leis universais. Neste caso, não precisaríamos ir além do conceito de Direito na busca por um fundamento para exercer a coação sobre alguém que esteja agindo em desconformidade com um uso universal da liberdade; afinal, devido à natureza coercitiva do Direito, tudo o que ele visa é justamente possibilitar um uso correto da liberdade externa de acordo com uma lei universal, permitindo assim a proteção da independência de cada um em relação aos demais. Assim, a autorização para coagir quem limita meu direito estaria contida analiticamente no conceito de uma ação legítima ${ }^{5}$. Desta forma, no entender de Wood a função do Direito é a proteção da liberdade externa, entendida esta como independência em relação a uma possível coerção que ela possa sofrer por parte do arbítrio do outro. Na medida em que um uso indevido que alguém faz de seu arbítrio fere minha liberdade, eu estou autorizado a coagi-lo na mesma proporção em que fui afetado.

Segundo Wood, o princípio do Direito, assim como já assinalara Willaschek, nos diz apenas quais ações infringem a liberdade externa, porém não seria sua função nos obrigar a agir coagidos internamente, como faz o princípio moral. Diferente deste, o princípio do direito nos informa quais ações seriam corretas e quais infringem a liberdade externa. $\mathrm{O}$ critério da legalidade externa do Direito não menciona o que um ser racional poderia desejar que fosse uma lei universal. Aqui Wood está se referindo ao âmbito interno, no sentido de que a legislação jurídica não exige um vínculo com a lei que não o puramente externo. Portanto, o sistema do Direito estaria desvinculado da Ética, já que não precisaria dela para estabelecer um sistema de deveres ${ }^{6}$.

\footnotetext{
${ }^{4}$ Cf. Ibid, p. 77-87.

${ }^{5}$ Cf. WOOD, A. The final form of Kant's practical philosophy. In: TIMMONS, Mark (org). Kant's metaphysics of morals. Oxford: Oxford University Press, 2002, p. 6-7.

${ }^{6}$ Cf. Ibid. p. 8-9.
} 
Wood chega a reconhecer que os deveres jurídicos poderiam ser tomados como deveres éticos indiretos, e, neste caso, na Metafísica dos Costumes Ética e Direito pertenceriam à Filosofia prática (moral), podendo ser deduzidos do imperativo categórico. Contudo, no que tange ao Direito estrito esta formulação não poderia ser sustentada, sendo o Direito totalmente independente do imperativo categórico. Em outro texto Wood é bem claro a esse respeito afirmando que embora na esfera do Direito se possa derivar o conceito de dever do imperativo moral, disso não se segue que o suposto imperativo seja fundamento dos deveres jurídicos, afinal, o sistema jurídico é um sistema recursivamente fechado e por isso não precisaria de princípios morais externos para o seu funcionamento, embora Kant considere que ele poderia ser apoiado "de fora" por tais princípios ${ }^{7}$. Embora Kant admita que o discurso do Direito seja normativo, estipulando um conjunto de normas que deve adequar-se a certos padrões racionais, tais padrões não são morais ou éticos, mas padrões do Direito e por isso apropriados a um sistema social de coerção (por meio da lei civil e criminal) $)^{8}$. Por isso então que o Direito poderia endossar qualquer tipo de instituição que seja substancialmente justa, mesmo que os valores das pessoas que dela participam sejam distintos daqueles da Filosofia prática. E isso resultaria numa grande vantagem para a teoria do Direito de Kant, pois ela poderia ser aplicada a uma sociedade em que as pessoas não subscrevem princípios morais kantianos ${ }^{9}$.

Passamos agora a um breve comentário dessas duas posições e concentraremos a atenção em dois problemas: a normatividade e a analiticidade do Direito. Ambos os autores corretamente afirmam que o Direito é analítico e é deduzido da liberdade externa, afinal, como o próprio Kant menciona na Metafísica dos Costumes, no âmbito jurídico cada um pode escolher subjetivamente o fim para suas ações. Contudo, o conceito de liberdade externa resultante das análises desses autores desconecta o Direito da razão prática. A questão é que, na sua compreensão, o Direito não seria um sistema normativo, porque para ser normativo precisaria ter como seu fundamento o imperativo categórico, que é próprio da Ética strito sensu, e o Direito estrito não se encaixaria neste tipo de formulação. De nosso ponto de vista, o Direito é muito mais que uma 'mera autorização' para coagir, afinal, a suposta autorização é uma decorrência natural do caráter normativo das leis jurídicas ${ }^{10}$, muito embora concordemos com eles que o Direito não está submetido ao imperativo categórico da Ética. Com isso, a regulação da liberdade externa (bem como os deveres jurídicos que estariam na sua base) não poderia se dar por quaisquer leis de caráter pragmático,

\footnotetext{
${ }^{7}$ Cf. WOOD, A. Kant. Trad. Delamar José Volpato Dutra. Porto Alegre: Artmed, 2008, p. 205.

${ }^{8}$ Cf. Ibid, p. 206.

${ }^{9}$ Cf. WOOD, A. The final form of Kant's practical philosophy. In: TIMMONS, Mark (org). Kant's metaphysics of morals. Oxford: Oxford University Press, 2002, p. 10.

${ }^{10}$ Daremos mais detalhes acerca da normatividade no Direito logo à frente neste item.
} 
por exemplo, já que nestas os fins podem atender a diversos interesses, enquanto que uma lei fundada na razão prática estabelece uma condição em que qualquer súdito pode identificar-se como um colegislador, já que esta lei veicula um interesse realmente comum a todo o povo.

Mas, se o Direito não está fundado no imperativo categórico, como pensá-lo numa conexão com a razão prática de modo que ele possa ser considerado um sistema normativo? A resposta desta questão nos permitirá adiantar nossa objeção ao segundo grupo (tese da dependência), pois ela nos possibilita pensar que o sistema jurídico, mesmo sendo analiticamente derivado da liberdade externa, precisa de um princípio sintético que lhe dê sustentação, a fim de que o Direito possa ser pensado como parte do sistema da Metafísica dos costumes e assim não seja rebaixado às fileiras da Filosofia pré-crítica.

Kant diz que o Direito deriva analiticamente da liberdade externa. E isto é ponto pacífico. Contudo, desde a Primeira crítica Kant deixa claro que: (1) a liberdade, quer interna, quer externamente, só pode ser pensada como uma ideia reguladora da ação, mas não conhecida diretamente. Ela só pode ser conhecida indiretamente por meio do conhecimento da lei moral, cuja consciência permanente nunca pode ser apagada, a qual é como se fosse um factum da razão. Portanto, também no Direito não se pode fundamentar diretamente os deveres jurídicos na liberdade, a qual permanece incognoscível e cuja demonstração depende de sua consequência. Em outros termos, dizer que o Direito deriva analiticamente da liberdade não basta para fundamentar um dever jurídico, afinal, a liberdade não se prova por si mesma; (2) Kant também não afirma que o princípio do Direito é o único princípio para se deduzir deveres jurídicos, mas insiste tanto em Teoria e práxis $^{11}$, como na Introdução à doutrina da virtude ${ }^{12}$ que os deves jurídicos provêm da vontade unificada do povo. Além disso, quando do tratamento do Direito privado na Metafísica dos Costumes, Kant mostra que o princípio do Direito (que é analítico) fundamenta a posse empírica com a detenção física do objeto, pois quem me retira de um lugar pela força ou toma de minhas mãos um objeto que detenho fisicamente, age contra o meu interior, contra a minha liberdade inata, mas só a vontade unificada do

\footnotetext{
11 “Com efeito, todo o Direito depende das leis. Mas uma lei pública que determina para todos o que lhes deve ser juridicamente permitido ou interdito é o ato de um querer público, do qual promana todo o Direito e que, por conseguinte, não deve por si mesmo cometer injustiças contra ninguém. Ora, a este respeito, nenhuma outra vontade é possível a não ser a de todo o povo (já que todos decidem sobre todos e, por conseguinte, cada um sobre si mesmo): pois só a si mesmo é que ninguém pode causar dano [...], por conseguinte, nenhuma vontade particular pode ser legisladora para um corpo comum". TP, AA 08: 294-5. 12 "Só que na Ética esta lei (o imperativo categórico) é pensada como a lei da própria vontade, não da vontade geral, que também poderia ser a vontade dos outros, caso em que daria origem a um dever jurídico, que não pertence ao domínio da Ética". MS, AA 06: 389 (parênteses acrescentados).
} 
povo fundamenta a posse meramente jurídica sem a detenção física do objeto, pois só uma vontade omnilateral pode determinar que os demais se abstenham de usar um objeto externo de meu arbítrio ${ }^{13}$. Logo, os dois princípios (o princípio do direito e a vontade unificada) são necessários para fundamentar os deveres jurídicos, mas só a vontade unificada do povo prova que a posse meramente jurídica é um juízo sintético a priori, pois é esta vontade que produz a lei moral no âmbito jurídico. Logo, a conclusão mais correta é que o princípio do Direito é analítico. Assim, para que os deveres jurídicos sejam sintéticos, como Kant demostrou no caso da "dedução da posse meramente inteligível", é necessário pressupor que há um outro princípio que colabora com o princípio do Direito na fundamentação dos deveres jurídicos, que é a vontade unificada do povo. Com isso, pode-se concluir que o princípio da vontade unificada é aquele elemento sintético que complementa o princípio do Direito, dando ao sistema jurídico o caráter normativo que só a razão prática pode dar. Sem o suposto princípio certamente que seria possível um sistema jurídico, mas este não estaria fundado na razão prática.

Com isso, a partir desse complemento da vontade unificada ao princípio do Direito, teríamos a explicação para um sistema coercitivo que poderia ser justificado pela razão prática, cabendo ao Direito a função de coagir um uso indevido da liberdade e à vontade unificada fornecer a normatividade dos deveres. Isto implica que o Direito só coage baseado na normatividade posta pela vontade unificada, o que nos leva a concluir que nem todo sistema coercitivo poderia ser aceito como justo, mas apenas aquele cujas leis pudessem ser consentidas pelo povo inteiro (idealmente). Segundo Kant, só uma vontade que é comum a todos teria o poder de gerar uma obrigação que não onere mais a uns do que a outros através de leis universais. Esta vontade, no estado de natureza é apenas uma ideia a priori, porém no Estado civil manifesta-se através do legislativo, o qual representa todo um povo e assim a lei que dela promana não poderia ser injusta com ninguém ${ }^{14}$.

A partir desse esclarecimento, já podemos perceber que a autorização para coagir todo aquele que põe um obstáculo a um uso universal da liberdade não pode ser uma 'mera autorização' desprovida de caráter prescritivo. Afinal, da liberdade externa e suas leis temos ciência por meio da consciência da lei moral derivada da vontade unificada, vontade essa que é sempre geral e por isso não pode causar danos a ninguém já que não onera mais a uns do que a outros. Sem esta consciência da lei que provém da vontade de todo o povo, não seria possível conhecer nossa liberdade e quais as leis que a regem. Neste sentido, devemos interpretar

${ }^{13}$ Cf. MS, AA 06: 263.

${ }^{14}$ Cf. MS, AA 06: 313. 
a expressão "lei universal de liberdade", a qual faz parte do princípio do Direito, como uma lei oriunda da razão prático-jurídica, isto é, como uma lei que só pode ser dada pela vontade de um povo inteiro (idealmente). Só assim podemos falar que esta lei universal provém de nossa própria razão e expressa uma independência do arbítrio, isto é, expressa a autêntica liberdade externa. Perceba-se, então, que o arbítrio só pode ter sua independência garantida porque a lei que regula todos os demais arbítrios é uma lei que emana da razão prática legisladora, isto é, emana de uma vontade unificada e comum a todo o povo. Se assim não fosse, certamente que esta independência estaria comprometida, pois a vontade da qual descenderia não seria geral. Poderia até ter uma camuflagem de universalidade, porém, dado que resultaria de acordos e negociações, sua base de sustentação seria frágil e facilmente sucumbiria, enquanto que aquela fundada na vontade geral resiste às vicissitudes, em virtude de seu fundamento a priori, isto é, em virtude de atender a um interesse comum a todos os cidadãos.

Ora, este caráter normativo da Filosofia prático-jurídica não pode ser negado. Ele é obtido por meio da lei que promana da vontade unida, tornando assim possível a liberdade externa. Neste sentido, o problema da interpretação de Willaschek é que ele compreende normatividade como coerção interna apenas e o que acabamos de mostrar é que mesmo as leis que provém da vontade geral (âmbito externo) estão carregadas de normatividade, pois descendem da razão prática. Ousaríamos dizer que se o Direito kantiano não fizesse tal exigência prática, Kant não precisaria ter-se dedicado a elaborar uma teoria do Direito, afinal, este poderia ser obtido por meio de qualquer teoria com teor pragmático, utilitário, etc. Neste caso, o Direito não poderia fazer parte da Metafísica. Mas, como veremos no item 4, o Direito é composto por princípios a priori e é um dos ramos da Metafísica dos Costumes e por isso o sistema de deveres deve ter uma ancoragem em algum princípio sintético.

\section{Tese da dependência}

Um segundo grupo de pesquisadores defende a teoria da dependência do Direito em relação à Ética. Guyer, por exemplo, afirma que o princípio do Direito é analítico e deriva da liberdade externa, visto que este princípio apenas afirma as condições sob as quais a liberdade pode ser usada de acordo com uma lei universal. Contudo, para Guyer, ainda que certos princípios do Direito tenham a mesma estrutura lógica dos juízos analíticos, é improvável que Kant quisesse torná-los válidos apenas por uma análise de seu conceito, até porque, uma cadeia de inferências lógicas seria insuficiente para demonstrar que uma proposição poderia ser 
conhecida apenas por meio da lógica. ${ }^{15}$ Uma prova por contradição não poderia provar a necessidade do princípio. Conforme Guyer, “[...] Kant precisa explicar como o uso da coerção pode preservar a liberdade e por que apenas ele (o uso da coerção) pode fazê-lo"16. E certamente que este tipo de exigência não poderia ser sustentada apenas por um juízo analítico. Contudo, Guyer reconhece que Kant, entretido como estava com as relações lógicas do princípio jurídico, acabou não elaborando uma dedução direta da obrigação jurídica a partir do imperativo categórico. Não obstante, como nenhum juízo analítico sustenta-se por si só, ele precisa de algum ponto de ancoragem em alguma entidade sintética, de modo a se poder justificar a obrigação que ele veicula. Neste caso, mesmo sendo o Direito derivado da liberdade externa, a sua normatividade precisa estar ancorada no imperativo categórico, o qual não teria outra função senão dar a conhecer a nossa liberdade. Nas suas palavras:

Para os princípios de direito, a única fundamentação não-arbitrária disponível é o conceito de liberdade, a prova da realidade objetiva que é, por sua vez, o tema fundamental da filosofia prática de Kant, resolvida em última instância pela validação de nossa assunção de nossa liberdade por meio de nossa consciência da força obrigatória do Imperativo Categórico ${ }^{17}$.

Portanto, é através do imperativo categórico que tomamos conhecimento de nossa liberdade externa e é ele o princípio por meio do qual esta seria limitada, de modo que, tomando-o por base, poderíamos determinar tanto os nossos direitos que são impostos legalmente, quanto nossos deveres éticos ${ }^{18}$. Com isso Guyer sugere que haveria uma dependência do Direito em relação à Ética, em relação ao princípio fundamental da moralidade e com isso os deveres jurídicos expressariam uma normatividade fundada no imperativo categórico da Ética.

A pergunta que surge agora seria: em que termos esta normatividade poderia ser pensada? Exigiria esta dependência normativa, além da conformação externa da lei ao dever ainda uma adesão motivada pelo dever? Lembremos que, segundo Willaschek, a exigência motivacional feita pelo imperativo categórico foi um elemento que acabou afastando o Direito da Ética. Mas afinal, seria possível admitir o imperativo categórico como fundamento de leis que exigem apenas "legalidade"?

Um comentador que responde a esta questão é Guido de Almeida. Como Guyer ele reconhece a dependência do Direito em relação à Ética, enfatizando que as leis jurídicas seriam um caso especial das leis éticas e assim

${ }^{15}$ Cf. GUYER, P. As deduções de Kant dos princípios do direito. In: TRAVESSONI GOMES,

A. (org). Kant e o Direito. Belo Horizonte: Mandamentos, 2009, p. 301-4.

${ }^{16}$ Cf. Ibid, p. 332.

${ }^{17} \mathrm{Ibid}, \mathrm{p} .307$.

${ }^{18}$ Cf. Ibid, p. 296. 
os princípios do Direito ${ }^{19}$ seriam derivados do princípio moral. Dado que há em Kant um conceito moral de Direito, as leis jurídicas, em sendo uma espécie das leis morais, estariam legitimadas a coagir a quem a elas não se adequa, já que o Direito é uma faculdade moral de realizar o que é lícito e o que é obrigatório, assim como de não fazer o que é proibido e por isso poderia coagir pela força quem nos impede de realizá-lo ${ }^{20}$.

Neste sentido, as leis jurídicas não excluem a conformidade incondicional em relação ao imperativo categórico. Isto porque, a incondicionalidade estaria relacionada à obrigatoriedade da lei, quer esta deva ser cumprida por de ver, quer conforme ao dever. É a lei e não a motivação aquilo que determina a prescritividade ${ }^{21}$. Neste caso, o que varia é apenas o modo de obrigação no intuito de transformar a prescrição da lei em uma ação concreta. Em outros termos, na interpretação de Almeida uma lei jurídica não deixaria de ser obrigatória pelo fato de ser imposta coercitivamente, afinal, o âmbito da coerção, que na Ética é exclusivamente interno, no Direito pode ser também externo, toda vez que a lei não é cumprida por uma coação interna do dever.

Segundo Almeida, sua posição encontraria apoio em duas teses de Kant. A primeira seria a afirmação de que a todo dever corresponde um direito, no sentido de que haveria uma autorização ou uma faculdade moral de fazer não só o que é exigido, mas o que é lícito e também de não fazer o que é proibido; a segunda mostra-se no fato de Kant demonstrar que o Direito está conectado à faculdade moral de usar a coerção, do que se concluiria que a legislação jurídica é tornada possível pela própria moralidade, sendo o Direito fundamentalmente um direito moral de coagir pela força aquilo que é exigido pela lei moral ${ }^{22}$.

\footnotetext{
${ }^{19}$ Guido esclarece que o Princípio Universal do Direito seria um princípio de avaliação ("uma ação é conforme ao Direito quando permite ou quando sua máxima permite fazer coexistir a liberdade do arbítrio de cada um com a liberdade de todos segundo uma lei universal"), enquanto que a Lei Universal do Direito seria um princípio de execução ("age exteriormente de tal modo que o uso livre do teu arbítrio possa coexistir com a liberdade de cada um segundo uma lei universal"). Cf. ALMEIDA, Guido A. de. Kant e o princípio do Direito. In: TRAVESSONI GOMES, A. (org). Kant e o Direito. Belo Horizonte: Mandamentos, 2009, p. 359.

${ }^{20}$ Cf. Ibid, p. 372.

${ }^{21}$ Cf. Ibid, p. 368.

${ }^{22}$ Cf. Ibid, p. 369. Kersting é outro comentador que também pactua com a tese da dependência e cuja solução ao problema em questão se aproxima desta defendida por Almeida. Segundo ele, além do seu aspecto externo, o Direito possui um lado interno de caráter obrigacional, de modo que a indiferença do Direito em relação à motivação não pode ser entendida como independência em relação à obrigatoriedade moral. Dado que nossa liberdade só pode ser conhecida através do imperativo moral, "sem a experiência do dever ser incondicional da lei moral em nós, explicitada na filosofia da moral, seria incompreensível o discurso da obrigatoriedade da lei jurídica" (Cf. KERSTING, W. O fundamento de validade da moral e do direito em Kant. In: TRAVESSONI GOMES, Alexandre. (org). Kant e o Direito. Belo Horizonte: Mandamentos, 2009, p. 168). Por isso, a auto-obrigação, que no âmbito interno seria uma relação da pessoa consigo mesma (enquanto legisladora racional coagindo o próprio arbítrio
} 
Portanto, esta resposta nos parece uma solução plausível a um problema visto como insolúvel por Willaschek, o qual concluíra ser impossível aplicar a prescrição do imperativo categórico no âmbito do Direito, o que contribuiu para a sua concepção não prescritiva do Direito. Não obstante, se nossa interpretação estiver correta, a questão da prescritividade é um falso problema, já que a liberdade externa, à qual o Direito está analiticamente ligado, não está vinculada ao imperativo categórico da Ética, mas ao imperativo do Direito e este à lei moral oriunda da vontade unida do povo. Afinal, no Direito a ideia de obrigação origina-se da vontade unida, sendo esta a fonte última de justificação para os deveres jurídicos e não o imperativo categórico como propõem os defensores da tese da dependência.

\section{Tese da Complementariedade}

Uma terceira posição acerca da relação entre Ética e Direito é defendida por Christoph Horn. Em sintonia com Willaschek, sua interpretação também vê como problemática a aceitação do imperativo categórico como fundamento do ordenamento jurídico. Assim como Willaschek, Horn também faz objeções à tese da dependência. Ele considera que, se aceitarmos que o imperativo categórico tem seu traço principal na motivação moral, isso evidencia que ele não poderia ser a base para se pensar as leis jurídicas, já que o Direito se limita apenas à regulação externa dos arbítrios, deixando inteiramente de lado o aspecto da motivação moral. Para se pretender estabelecer um sistema jurídico a partir do imperativo ético, seria preciso dissociá-lo do aspecto motivacional (sua característica essencial), ou então, uma segunda alternativa seria moralizar o sistema jurídico. Ocorre que, para Kant, ambas alternativas seriam inaceitáveis ${ }^{23}$.

Além desta objeção que consideramos central, Horn ainda sugere uma objeção secundária (entre outras) ligada ao conceito de liberdade. Segundo ele, o conceito de liberdade no âmbito jurídico-político seria um conceito totalmente distinto daquele exigido pelo imperativo categórico, o qual teria como base a liberdade transcendental enquanto liberdade inteligível. Por sua vez, a liberdade jurídica seria uma liberdade externa e estaria ligada à liberdade de escolha da própria felicidade, da forma de vida ${ }^{24}$.

enquanto fenômeno), é transformada, no âmbito jurídico, numa obrigação externa intersubjetiva, isto é, a legislação interna se transforma em externa e assim a coerção jurídica acaba sendo a contrapartida externa da autocoação moral. Ou ainda, a coerção jurídica legítima seria o equivalente patológico do poder de motivação ética. Cf. Ibid, 169-70.

${ }^{23}$ Cf. HORN, Christoph. Qual é o fundamento da Filosofia política de Kant? In: Studia Kantiana, v.7, n.8, 2009, p. 46.

${ }^{24}$ Cf. Ibid, p. 47. Há outras objeções que julgamos secundárias ligadas à recusa de um fundamento moral para o Estado, as quais fogem aos propósitos deste estudo e poderão ser consultadas no texto do autor. 
Embora haja, por parte de Horn, uma rejeição da tese da dependência, ele também não compactua com a tese da independência, defendendo um ponto de vista alternativo em que procura situar Direito e Ética como partes da razão prática, mas cada um com sua especificidade. Neste sentido, o imperativo do Direito seria um postulado normativo, porém não com aquele peso moral ideal próprio da Ética. Haveria, sim, certas exigências feitas pela razão, porém a elas se responderia de forma análoga e comparativa ao teste feito pelo imperativo categórico (mas não nos mesmos termos), já que no Direito este procedimento é feito pelo teste da vontade unida do povo, a qual mostra que somente aquelas leis que poderiam ser consentidas por todo um povo (idealmente) seriam legítimas e por isso deveriam ser aceitas como provenientes da razão legisladora. Além disso, e diferente da Ética, o procedimento no Direito abdica da motivação. Portanto, o fato de que tenhamos procedimentos diferentes, bem como critérios distintos para se estabelecer os respectivos sistemas de deveres, isso leva Horn a concluir que o Direito não é nem dependente, nem independente da Ética, mas juntos se complementam e compõem o sistema dos deveres no âmbito da Metafísica dos costumes ${ }^{25}$.

De nossa parte endossamos a tese de Horn, embora devamos fazer um esclarecimento acerca de sua interpretação da liberdade externa. Certamente que o conceito de liberdade tem a ver com a independência em relação a uma possível interferência do arbítrio alheio no meu arbítrio, porém esta independência é apenas metade da moeda. A outra metade está no aspecto positivo. Neste sentido, pode-se dizer que a independência só pode efetivar-se porque a lei que me permite ser livre descende da vontade geral (que é também a minha própria vontade). Eu, enquanto membro da vontade unida (idealmente), me reconheço na lei que esta vontade promulga e a assumo como minha própria lei. Como esta lei deve valer para todos indistintamente, ela só pode estar fundada num querer comum. Por isso que, assim como a lei moral dá a conhecer nossa liberdade no âmbito interno, assim também as leis jurídicas, originadas da vontade unida, dão a conhecer nossa liberdade no âmbito externo. E assim a razão prática mostra-se sob os dois aspectos de sua legislação, bem como de suas leis.

Partindo dessa tese de Horn como pano de fundo de nossa interpretação, vamos apresentar um detalhamento da relação entre Direito e Ética a partir do texto da Metafísica dos Costumes, e, apesar de alguns problemas ligados especialmente à divisão dos deveres, a tese da complementariedade parece ser a que melhor expressa o pensamento de Kant.

${ }^{25}$ Cf. Ibid, p. 51. 


\section{Uma análise da relação entre Ética e Direito na Metafísica dos Costumes}

Grosso modo, pode-se dizer que na Metafísica dos Costumes Kant visa estabelecer um sistema dos deveres, de tal modo que fique completo o campo de ação da razão prática e esta não seja confundida com a mera natureza. Por isso que já no preâmbulo desta obra ele menciona: "à crítica da razão prática deveria seguir-se o sistema, a metafísica dos costumes, que se divide em princípios metafísicos da doutrina do Direito e princípios metafísicos da doutrina da virtude (como contraponto aos princípios da ciência da natureza, já apresentados)"26.

Logo a seguir, Kant confirma que o Direito é parte do sistema emanado da razão: "à doutrina do Direito, como primeira parte da doutrina dos costumes, o que é pedido é um sistema emanado da razão, aquilo que se poderia chamar de metafísica do Direito"27.

O intuito de trazer estes excertos é mostrar que em Kant Ética e Direito compõem um grande sistema da razão prática, que podemos chamá-lo de sistema moral ${ }^{28}$. São duas partes de um grande corpo. Porém, há que se ter o cuidado para não se dirimir o Direito na Ética; ou ainda, evitar pensar o Direito totalmente desprovido de qualquer fundamento na razão práti$\mathrm{ca}$, o que conduziria à heteronomia. Afinal, se Kant visa estabelecer um sistema com dois subsistemas, isso implica que as duas partes do sistema são diferentes entre si e possuem suas especificidades.

Considerando então que Ética e Direito são os dois componentes do sistema moral, pode-se dizer que a fonte de todo o dever é a própria razão prática, seja esta compreendida como Ética stricto sensu, seja como um sistema dos deveres jurídicos, de tal forma que ambos os sistemas compreendem o que Kant denomina de "leis da liberdade"29. O intuito dessas leis é dar a conhecer nossa liberdade, seja do ponto de vista interno (Ética), seja do externo (Direito). Por isso então que nelas estão implicadas tanto as éticas quanto as jurídicas.

\footnotetext{
${ }^{26}$ MS, AA 06: 205. Na introdução à Metafísica dos Costumes Kant apresenta graficamente a moral como um "sistema de deveres em geral". Ali menciona que a doutrina elementar divide-se em deveres jurídicos e deveres de virtude. Cf. MS, AA 06: 242.

${ }^{27}$ MS, AA 06: 205.

${ }^{28}$ Queremos esclarecer que 'moral' ou 'sistema moral' neste contexto não se refere à Ética stricto sensu, tal como fundamentada na Fundamentação, mas trata-se da moral compreendida como um amplo sistema da razão prática, o qual compreende a Ética e o Direito.

29 "Estas leis da liberdade chamam-se morais, em contraposição às leis da natureza. Na medida em que estas leis morais se referem a ações meramente externas e à sua normatividade, denominam-se jurídicas; mas se exigem, além disso, que elas próprias (as leis) constituam o fundamento determinante das ações são leis éticas [...]”. MS, AA 06: 214.
} 
No tocante à Ética, a vontade produz a lei moral (razão prática no âmbito interno) e esta coage internamente o arbítrio para que ele estabeleça máximas que conduzam a uma ação motivada pelo dever e o indivíduo possa ser livre internamente. Esta coação manifesta-se por meio do imperativo categórico que reza: "age segundo uma máxima tal que possas ao mesmo tempo querer que ela se torne lei universal"30. Aqui a lei moral está determinando internamente a máxima do agente para que este cumpra o dever motivado pelo próprio dever. Em outros termos, a lei moral, por meio da consciência do dever, exerce uma autocoação sobre o arbítrio, a fim de que este adote o dever como matéria da máxima. Por isso, os deveres da liberdade interna determinam, além da forma, a matéria do arbítrio, isto é, um fim para a ação, fim este que na Ética será sempre um dever, já que se trata de um fim objetivamente necessário e a priori e por isso é independente das inclinações ${ }^{31}$.

Já no tocante ao Direito, a vontade unificada do povo (minha vontade e de cada outro) produz a lei moral (razão prática no âmbito externo) no âmbito jurídico, a qual coage apenas externamente o arbítrio, produzindo assim a liberdade externa. Esta coação ocorre através do imperativo do Direito que diz: "age exteriormente de tal modo que o uso livre do teu arbítrio possa coexistir com a liberdade de cada um segundo uma lei universal"32. Aqui no âmbito jurídico, a razão prática manifesta-se como vontade unida do ovvo $^{33}$, pois é dela que decorre todo Direito, já que é a única que pode legislar e não cometer injustiça contra ninguém (a vontade particular é facilmente parcial), pois expressa um acordo ideal em que cada um decide o mesmo sobre todos e todos sobre $\mathrm{um}^{34}$. O Direito decorre dela já que ela é a fonte de toda lei, e assim a liberdade externa é produto desta lei que emana da vontade pública. Portanto, ser livre significa seguir a lei da razão: no âmbito interno, a lei da própria vontade; no externo, a lei que emana da vontade geral. Então o Direito, em sendo o conjunto das condições que regula os arbítrios segundo uma lei universal de liberdade ${ }^{35}$, não é outra coisa senão a expressão, no âmbito externo, da própria razão prática legislando a forma dos arbítrios, exigindo assim apenas a conformação externa dos arbítrios à lei, de modo que o agente possa escolher qualquer móbil para sua ação, já que o Direito não impõe fins ${ }^{36}$. Não há

\footnotetext{
${ }^{30}$ MS, AA 06: 225.

${ }^{31}$ Cf. MS, AA 06: 380.

${ }^{32}$ MS, AA 06: 231.

33 Salientamos que a vontade unida do povo não é um conceito empírico, mas uma ideia reguladora prática a priori e expressa um consenso ideal, a ideia de um Estado fundado num contrato originário, em que a união das vontades decidiriam sempre de forma legal e justa. Assim, um Estado fundado no contrato originário teria no coração de seu legislativo promulgações que beneficiariam a todos indistintamente porque o conteúdo das leis visaria um interesse comum a todos, um interesse da razão. Cf. TP, AA 08: 297.

${ }^{34}$ Cf. MS, AA 06: 314.

${ }^{35}$ Cf. MS, AA 06: 230.

${ }^{36}$ Cf. MS, AA 06: 230.
} 
aqui qualquer exigência de que também internamente os sujeitos sejam motivados pelo dever quando cumprem o que a lei determina. Por isso então que os deveres da legislação jurídica serão somente deveres externos, já que esta legislação não exige que a ideia do dever, que é interna, seja fundamento de determinação da máxima do arbítrio ${ }^{37}$.

Com isso podemos perceber que Ética e Direito possuem diferentes legislações, as quais se distinguem pelos móbeis de suas ações. A legislação ética é aquela que faz de uma ação um dever e desse dever um móbil, enquanto que a legislação jurídica admite um móbil diferente do próprio dever, visto que não está preocupada com a motivação do agente, mas apenas com o aspecto externo da ação ${ }^{38}$. Por isso então que a coação na Ética será sempre autocoação, isto é, a lei coage internamente o arbítrio do agente a fim de que sua ação seja motivada por uma máxima cujo fim é um dever, enquanto que no Direito a coação será externa. Daí que na Ética sempre deverá haver virtude no cumprimento do dever, elemento este não necessário no Direito.

Os deveres éticos (deveres de virtude) são chamados por Kant de deveres imperfeitos. Isso porque são deveres de obrigatoriedade ampla e assim não se pode determinar com precisão a intensidade e o grau com que se deve realizar uma ação com vistas ao fim que é simultaneamente um dever ${ }^{39}$. O sentido desta "imperfeição" pode ser compreendido da seguinte maneira: quando Kant diz que a todo dever corresponde um direito por parte de outrem ${ }^{40}$, isso está claro no âmbito jurídico em que os deveres são perfeitos e determinam um comportamento preciso. Já com relação aos imperfeitos não há uma medida precisa do quanto devamos cuidar de nossa perfeição física, por exemplo, ou, ainda, até onde deve ir nossa beneficência em relação aos necessitados.

Kant classifica em duas categorias os deveres de virtude: deveres em relação à própria perfeição (a humanidade na minha pessoa) e deveres em relação à felicidade alheia (a humanidade na pessoa do outro), os quais são deveres que são fins (a priori $)^{41}$. Consequentemente, se os deveres são imperfeitos, também a coerção será imperfeita, já que não dispõe da precisão do quanto coagir. Por isso então que na Ética o conceito de mérito é muito importante, já que permite pensar uma ação com mais ou menos virtude, isto é, com uma máxima mais ou menos motivada (e coagida) pelo dever, tendo em vista que a liberdade interna aumenta à medida que o arbítrio afasta a coerção dos impulsos da sensibilidade e se deixa coagir

\footnotetext{
37 Cf. MS, AA 06: 219.

38 Cf. MS, AA 06: 219.

${ }^{39}$ Cf. $M S$, AA 06: 390; 411.

${ }^{40}$ Cf. MS, AA 06: 383.

${ }^{41}$ Cf. MS, AA 06: 390.
} 
pela lei moral. Podemos denominar este sistema da Ética que produz os deveres de virtude (deveres éticos diretos) como Ética stricto sensu, já que trata especificamente dos deveres éticos. Neste aspecto, a Ética compreende apenas os deveres de virtude, não levando em consideração os deveres jurídicos enquanto deveres éticos indiretos. Da mesma forma que a Ética, há também o Direito estrito (stricto sensu), cujos deveres não possuem nenhuma mescla com a Ética, embora, como o Direito faz parte do sistema da moral (razão prática), Kant nos lembra que ele "[...] fundamenta-se, na verdade, na consciência da obrigação de cada um segundo a lei" ${ }^{42}$, embora não possa apelar a esta consciência como móbil, já que no Direito a coação é externa.

Mas é preciso não confundir a virtude no cumprimento do dever com os deveres de virtude. A primeira tem a ver com a Ética lato sensu (veremos na sequência), e pode ser aplicada tanto aos deveres de virtude quanto aos deveres jurídicos, tratando-se da força da máxima no cumprimento do dever. Assim, quando, por exemplo, alguém, além de obedecer à lei do Estado, o faz por amor ao dever, pode-se dizer que é uma pessoa virtuosa, pois possui motivação moral em sua máxima e não está agindo por motivos patológicos, mas o faz com civismo. Por outro lado, os deveres de virtude são deveres exclusivos da liberdade interna, e não têm relação com os deveres jurídicos, já que determinam a máxima do agente.

Contudo, além de chamar de Ética ao conjunto dos deveres de virtude, Kant ressalta que "[...] todos os deveres, simplesmente porque são deveres, pertencem à Etica, o que, todavia, não quer dizer que a legislação de que procedem esteja por isso contida na Ética" ${ }^{43}$. Há aqui, por exclusão, uma clara referência aos deveres jurídicos, já que todos os deveres do sistema kantiano pertencem ou à Ética ou ao Direito. O que Kant parece afirmar é que todos os deveres jurídicos podem ser assumidos pela Ética como deveres éticos indiretos ${ }^{44}$, isto é, podem ser cumpridos com virtude. Portanto são deveres que, além da conformação externa da ação, podem ser assumidos como fundamento da máxima do agente, pois são apropriados pela legislação interna. Esta forma de pensar a Ética pode ser denominada de Ética lato sensu, já que se apropria de deveres que não são próprios do seu domínio e os torna seus deveres indiretos. Temos então aqui um conceito de Ética que extrapola o âmbito dos deveres de virtude e procura abarcar o domínio de todos os deveres.

Contudo, perceba-se que, o fato de poder a Ética assumir os deveres jurídicos como deveres éticos indiretos não torna o sistema jurídico dependente do

\footnotetext{
${ }^{42}$ MS, AA 06: 232.

${ }^{43}$ MS, AA 06: 219.

44 "Há, pois, decerto, muitos deveres éticos diretos, mas a legislação interior faz também de todos os restantes deveres, deveres éticos indiretos". MS, AA 06: 221.
} 
ético. Ao mesmo tempo, embora o Direito não exija que se leve em conta a motivação na elaboração das leis, não é menos verdade que a vontade unida jamais consentiria com leis injustas que disseminassem formas de discriminação, exclusão social, racial, etc. Uma lei, por exemplo, que admitisse a escravidão não poderia ser consentida pela vontade unida do povo, pois, embora de um ponto de vista pragmático e utilitário pudesse ser legitimada porque gera maiores lucros, estaria em total oposição com a razão prática. Por isso então que as leis jurídicas, embora não sendo originadas do imperativo categórico da Ética, poderiam ser assumidas por esta sem problemas. Ou seja, o que Kant parece afirmar é que, o fato de poder a legislação ética assumir os deveres jurídicos como seus deveres indiretos se deve não a uma dependência do Direito em relação à Ética, mas ao fato de que ambos são subsistemas da razão prática e assim não poderiam entrar em conflito entre si. Se isso ocorresse, haveria um paradoxo e uma cisão no interior da própria razão.

Tomando agora a questão do ponto de vista do Direito, ainda que a única legislação exigida por este seja a externa, isso não quer dizer que internamente a ação não possa ser cumprida com virtude, de modo que, além de uma adequação à forma da lei, se leve em conta a materialidade. Afinal, Kant diz apenas que a legislação jurídica "[...] admite um móbil diferente da ideia do próprio dever" ${ }^{\prime 5}$, mas não está excluindo que o dever seja também um móbil, confirmando assim, mais uma vez, que o âmbito do Direito não se importa com a motivação, não havendo nada que impeça que o indivíduo seja subjetivamente motivado pela liberdade interna. E quando assim procede, ele cumpre o dever jurídico com virtude, tornando-o um dever ético indireto, agindo não só com legalidade, mas também com autonomia. Contudo, há que ter presente que em momento algum a doutrina do Direito afirma que deva haver autonomia no cumprimento do dever jurídico. Apenas deixa livre para que o agente escolha o fundamento de sua máxima. Por isso então que Kant irá dizer que "a doutrina do Direito e a doutrina da virtude não se distinguem pois tanto pelos seus diferentes deveres como pela diferença da legislação [...]"46, pois os deveres jurídicos podem também ser assumidos pela Ética, porém o contrário jamais poderia ocorrer, já que a legislação ética é interna, e seus deveres são imperfeitos e por isso não definem ações e coerções precisas, enquanto que a jurídica é externa e perfeita, seja na definição do dever, seja na coerção. Além disso, há que ter o cuidado de não submeter ou mesmo dissolver o Direito na Ética, pois há deveres que são exclusivos do Direito e não podem ser confundidos com deveres de virtude, já que estes últimos são deveres de obrigação ampla (imperfeitos), enquanto que os deveres jurídicos são deveres perfeitos. Por isso, o fato de um dever

\footnotetext{
${ }^{45}$ MS, AA 06: 219.

${ }^{46}$ MS, AA 06: 220.
} 
jurídico ser assumido pela Ética como um dever ético indireto, não lhe pode retirar sua natureza jurídica, não sendo possível reivindicar qualquer forma de autocoação para ele, pelo menos no âmbito do Direito.

É importante fazermos ainda um esclarecimento quanto aos deveres internos e externos. De fato, às vezes se confunde os deveres da liberdade interna com os deveres internos; bem como os deveres da liberdade externa com os deveres externos. Conforme Durão, os deveres da liberdade interna ou externa são definidos pela matéria e a forma do arbítrio respectivamente. Assim, os deveres jurídicos são deveres da liberdade externa, pois levam em conta apenas a forma do arbítrio, enquanto que os deveres da liberdade interna são os deveres éticos (de virtude), já que levam em conta também a matéria do arbítrio (fim). Por sua vez, deveres internos e externos se explicam pela ação do agente. Assim, tem-se um dever interno quando a obrigação que manda realizar uma ação se dirige ao próprio sujeito, como, por exemplo, quando se diz que há um dever de cuidar da própria saúde; Já o dever externo ocorre quando a ação se dirige aos outros, como é o caso do dever de cuidar dos mais pobres. Neste sentido, entre os deveres da liberdade interna (deveres de virtude), pode haver tanto deveres internos (como o dever de cuidar da própria perfeição), quanto deveres externos (como é o caso dos deveres ligados à felicidade alheia). Entre os deveres da liberdade externa só pode haver deveres externos, já que a legislação da liberdade externa é externa ${ }^{47}$. E como nos deveres de direito a obrigação da ação sempre se dirige ao arbítrio do outro e não à própria pessoa, estes deveres serão todos externos.

Após esta breve exposição há algumas considerações a serem feitas em termos conclusivos. Primeiramente, Ética e Direito não podem ser confundidos, já que são diferentes tanto no conteúdo quanto na motivação. Do ponto de vista do conteúdo os deveres jurídicos, em sendo deveres da liberdade externa, são essencialmente diferentes dos éticos, pois nestes estão incluídos deveres internos, como, por exemplo, os deveres em relação à própria perfeição, enquanto que os jurídicos compreendem apenas deveres para com os outros (externos). Além disso, os deveres jurídicos não poderiam ser deveres da felicidade alheia, pois, conforme Kant, não cabe ao Estado legislar acerca da felicidade, pois, agindo assim, estaria sendo paternalista e o paternalismo constitui o pior dos despotismos, devendo, pois, apenas garantir a liberdade para que os próprios súditos escolham como querem ser felizes. Já do ponto de vista da motivação, os deveres jurídicos procedem da liberdade externa em que a vontade determina apenas a forma do arbítrio para a ação, enquanto que os deveres éticos procedem da liberdade interna, em que a lei moral determina também a

${ }^{47}$ Cf. DURÃO, A. B. O problema da Autonomia na Doutrina do Direito de Kant. In: SANTOS, L. Ribeiro dos (Org). Kant: posteridade e atualidade. Lisboa: CFUL, 2006, p. 396. 
matéria do arbítrio, isto é, o fim da ação, mas não a ação propriamente. Portanto, o Direito não pode ser dissolvido na Ética, mas também não se pode dizer que esteja desconectado do sistema moral.

Segundamente, é preciso considerar que a divisão dos deveres da $\mathrm{Me-}$ tafísica dos Costumes não é isenta de problemas ${ }^{48}$. Após ter definido os deveres de virtude como deveres imperfeitos e de latitude ampla, Kant elenca, na Doutrina da Virtude, uma série de deveres perfeitos para consigo compreendidos enquanto deveres de virtude. Dentre estes constam o suicídio, a masturbação e a mentira ${ }^{49}$. Portanto, essas afirmações geram uma dissonância na caracterização dos deveres. Apesar disso esse não é um problema de grande envergadura que comprometa a relação entre Ética e Direito, afinal, o fato de que entre os deveres de virtude (imperfeitos) Kant mencione alguns deveres perfeitos, não conduz a uma dissolução do Direito na Ética. Portanto, podemos considerar que um deslize desta índole não gera grandes prejuízos à teoria.

De maior prejuízo à sistematicidade da teoria é a introdução de um dever para consigo no âmbito do Direito. Lembremos que os deveres jurídicos são todos externos, perfeitos e em relação aos outros e nunca devem ser internos e direcionados ao próprio sujeito. Contudo, após ter feito esta ampla separação entre os deveres jurídicos e os de virtude, Kant postula um dever interno (honeste vive ${ }^{50}$, isto é, sê um homem honesto), introduzindo assim, no âmbito do Direito, um dever que seria próprio da Ética. A introdução de um dever interno para conosco (honeste vive) no âmbito do Direito acaba introduzindo uma inconsistência no Direito, pois se trata de um dever interno, e, como vimos anteriormente, os deveres jurídicos só podem ser deveres externos, pois envolvem apenas uma relação externa entre arbítrios. Além disso, possuem coação externa, o que não se verifica neste caso, pois eu não posso ser coagido externamente a não me converter num simples meio e ser ao mesmo tempo fim aos demais, pois aqui se está tratando de um estado interno de meu ânimo ao qual o Estado não tem acesso; além de que, não seria possível determinar uma ação específica para o direito de humanidade na minha pessoa, pois se trata de um dever imperfeito, sendo, portanto, um dever específico da liberdade interna (Ética) e não da externa (Direito).

\footnotetext{
${ }^{48}$ Pode-se consultar uma crítica ao sistema kantiano dos deveres em: WILLASCHEK, Marcus. Porque a Doutrina do Direito não pertence à Metafísica dos costumes: sobre algumas distinções básicas na Filosofia Moral de Kant. In: TRAVESSONI GOMES, Alexandre (Org). Kant e o direito. Mandamentos: Belo Horizonte, 2009, 257-292.

${ }^{49}$ Cf. MS, AA 06: 422-432.

50 "Sê um homem honesto (honeste vive). A honestidade jurídica (honestas iuridica) consiste no seguinte: em afirmar o seu valor como homem na relação com os outros - dever que se exprime pela proposição: "não te convertas para os demais num simples meio, mas sê para eles, ao mesmo tempo, um fim". Este dever será explicitado mais adiante como uma obrigação derivada do direito de humanidade na nossa própria pessoa (lex iusti). MS: AA 06: 236.
} 
Conforme Pinzani, o honeste vive exige que primeiro o ser humano se reconheça enquanto fim em si, enquanto um sujeito de liberdade para então entrar numa relação jurídica com o outro. E em vista desta relação que eu devo reconhecer minha humanidade. Do contrário, nenhum contrato teria validade. Por isso, a natureza desta obrigação é ambígua e assinala a passagem da dimensão ética do respeito pela dignidade humana em geral, àquela estritamente jurídica, que trata da afirmação da própria personalidade jurídica no confronto com os outros: constituiria um dever ético ser um homem honesto e isto tem a ver com o respeito à humanidade em minha própria pessoa; ao mesmo tempo um dever jurídico em relação aos outros no que respeita à nossa relação jurídica com eles. Por seu caráter ambíguo, esta obrigação não pode satisfazer plenamente nenhuma das condições que denotariam um dever ético ou jurídico ${ }^{51}$.

O esclarecimento de Pinzani é fundamental para captarmos a intenção de Kant, embora o impasse gerado no interior da teoria permaneça, já que não é possível desvencilhar completamente o teor ético do suposto dever, ficando nossa capacidade jurídica dependente de uma determinação ética. Poderíamos até mesmo alegar que Kant não precisaria lançar mão de tal dever, já que a consciência da lei moral em nós seria suficiente para se reconhecer que somos sujeitos suscetíveis de liberdade (e com isso, aptos às relações jurídicas), sem necessidade de termos ainda que afirmar nossa condição de homem honesto, nosso valor como humano. Não obstante, esta hipótese é descartada por Kant na própria Metafísica dos Costumes quando ele afirma que podemos perder a dignidade em virtude de nosso crime e assim ser convertidos em mero instrumento do arbítrio de outrem, e, consequentemente, inabilitados para qualquer relação jurídica ${ }^{52}$. Portanto, para Kant o criminoso não pode ser um sujeito jurídico e com isso uma eventual tese de que seríamos "naturalmente" aptos à condição de sujeitos jurídicos em virtude da lei moral em nós não poderia ser sustentada, do que podemos provisoriamente concluir que a inconsistência no interior da teoria permanece.

Em terceiro lugar vamos analisar que conclusões podem ser tiradas acerca da autonomia e da heteronomia no Direito. Na introdução à Metafísica dos Costumes, referindo-se às leis da liberdade, Kant diz que, no tocante ao aspecto externo das ações, tais leis denominam-se jurídicas. Mas, se elas próprias (as leis da liberdade) exigem ainda ser o fundamento determinante das ações, então são leis éticas. Por isso, Kant diz que "[...] a conformidade com as leis jurídicas é a legalidade da ação e a conformidade com as leis éticas é a moralidade" 53 .

${ }^{51}$ Cf. PINZANI, A. Sul rapporto tra morale, politica e diritto in Kant: alcune precisazioni. In: PINZANI, A; CODIGNOLA, M. M. Diritto, polltica e moralità in Kant. Milano: Paravia Bruno Mondadori Editori, 2004, p. 102-4.

${ }^{52}$ Cf. MS, AA 06: 329-30

${ }^{53}$ MS, AA 06: 215. 
O que este excerto nos mostra é que a legalidade seria própria do Direito, porque este não exige que a lei seja o fundamento determinante das máximas das ações. Porém, não há nada que impeça que tais leis se tornem o fundamento das ações e assim o agente possa agir com autonomia também no Direito. Mas poderíamos afirmar que o Direito é heterônomo? Conforme a mesma introdução da Metafísica dos Costumes, Kant diz que toda legislação, seja ela interna ou externa, possui um aspecto objetivo e um aspecto subjetivo. O elemento objetivo compreende a lei que representa objetivamente uma ação como necessária, convertendo assim tal ação em dever; o elemento subjetivo é o próprio móbil que liga o arbítrio à lei, que é fundamento da ação. Assim, por meio da lei a ação seria representada como um dever e por meio do móbil haveria a obrigação de agir em conformidade com o dever ${ }^{54}$. Segundo Durão, para que haja autonomia é preciso que os dois requisitos sejam preenchidos. Quando consideramos a legislação ética, percebemos que ela cumpre tanto o critério objetivo quanto o subjetivo da autonomia, pois objetivamente os deveres éticos são produzidos pela determinação da matéria do arbítrio pela vontade, e, subjetivamente, em sendo fins, os deveres determinam a máxima da ação do agente. Por sua vez o Direito cumpre apenas o critério objetivo, pois a vontade determina a forma da relação externa entre os arbítrios, mas não pode exigir que também subjetivamente a ação seja motivada pelo dever ${ }^{55}$. Isso demonstra que o Direito não preenche os requisitos da autonomia, pois lhe falta o elemento subjetivo. Porém não podemos simplesmente concluir que ele seja heterônomo, uma vez que o conceito de heteronomia implica na sujeição da minha vontade à vontade de outro. Lembremos que no Direito a lei emana da vontade unificada de todo o povo, a qual, expressando a ideia de um bem comum público, é também expressão da vontade de cada um. Assim, quando o legislativo, representando a vontade geral em ato (como um sistema representativo do povo), elabora leis baseadas na ideia a priori desta vontade pública, demonstra que indiretamente cada súdito está sendo um colegislador, seja pela representatividade que ele possui na pessoa dos deputados, seja pela coerção que a ideia da vontade geral exerce sobre os legisladores na hora de elaborar a lei. Deste modo, a ausência do elemento subjetivo não impede que a lei provenha da vontade legisladora universal, não havendo assim sujeição da minha vontade à vontade alheia. Portanto, ainda que não haja autonomia no Direito, não seria correto afirmar que ele é heterônomo.

Portanto, a conclusão a que chegamos é que Ética e Direito são subsistemas complementares que juntos compõem o grande sistema moral kantiano. Cada um tem seus deveres específicos, já que os procedimentos que

\footnotetext{
${ }^{54}$ Cf. MS, AA 06: 218.

${ }^{55}$ Cf. DURÃO, A. B. O problema da Autonomia na Doutrina do Direito de Kant. In: SANTOS,

L. Ribeiro dos (Org). Kant: posteridade e atualidade. Lisboa: CFUL, 2006, p. 404.
} 
dão origem a tais deveres são diferentes entre si: na Ética o imperativo categórico é a fonte dos deveres; no Direito, a vontade unida do povo. Mesmo assim, a Ética pode assumir os deveres jurídicos como seus deveres indiretos, pois a razão prática deve ter uma coerência interna. Em outros termos, o fato dos deveres jurídicos poderem ser assumidos pela Ética não se deve a uma submissão do Direito à Ética, mas ao fato de que há uma fonte comum que os une (a razão prática), e esta fonte não poderia estabelecer certos princípios e leis jurídicas que firam os princípios éticos. Se assim o fizesse, haveria uma contradição no interior da própria razão prática. Por isso que toda lei civil deve espelhar o princípio da vontade unida, já que esta traz no seu núcleo a ideia de um querer comum a todo o povo.

Endereço do Autor:

Rua Santo Antonio, 1110, Apto 104

B. Barreiros

88117-351 São José - SC

nilpellizza@gmail.com 